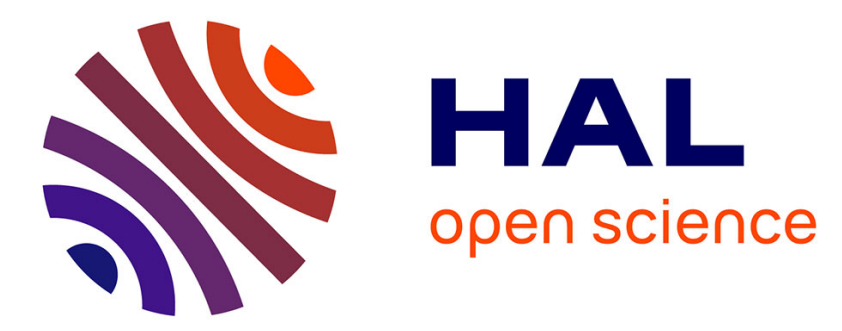

\title{
Kinetic study of spiramycin removal from aqueous solution using heterogeneous photocatalysis
}

\author{
A. Ounnar, L. Favier, A. Bouzaza, F. Bentahar, M Trari
}

\section{To cite this version:}

A. Ounnar, L. Favier, A. Bouzaza, F. Bentahar, M Trari. Kinetic study of spiramycin removal from aqueous solution using heterogeneous photocatalysis. Kinetics and Catalysis, 2016, 57 (2), pp.200-206. 10.1134/S0023158416020087 . hal-01329466

\section{HAL Id: hal-01329466 \\ https://hal-univ-rennes1.archives-ouvertes.fr/hal-01329466}

Submitted on 2 Nov 2016

HAL is a multi-disciplinary open access archive for the deposit and dissemination of scientific research documents, whether they are published or not. The documents may come from teaching and research institutions in France or abroad, or from public or private research centers.
L'archive ouverte pluridisciplinaire HAL, est destinée au dépôt et à la diffusion de documents scientifiques de niveau recherche, publiés ou non, émanant des établissements d'enseignement et de recherche français ou étrangers, des laboratoires publics ou privés. 


\title{
KINETIC STUDY OF SPIRAMYCINREMOVAL FROM AQUEOUS SOLUTION USING HETEROGENEOUS PHOTOCATALYSIS
}

\author{
A. Ounnar ${ }^{1,2}$, L. Favier ${ }^{3}$, A. Bouzaza ${ }^{3}$, F. Bentahar ${ }^{2}$, M. Trari ${ }^{4, *}$ \\ ${ }^{1}$ Centre de Développement des Energies Renouvelables (CDER), 16340, Algiers, Algeria \\ ${ }^{2}$ Université des Sciences et de la Technologie (USTHB), Faculté de Génie Mécanique et de Génie des \\ Procédés, Laboratoire des Phénomènes de Transfert, 16111, Algiers, Algeria \\ ${ }^{3}$ Laboratoire « Chimie et Ingénierie des Procédés », UMR 6226, Ecole Nationale Supérieure de \\ Chimie de Rennes, 35708, Rennes, France \\ ${ }^{4}$ Laboratory of Storage and Valorization of Renewable Energies, Faculty of Chemistry (USTHB), \\ BP 32, Algiers, Algeria \\ E-mail: solarchemistry@gmail.com
}

Receive 05.04.2015

\begin{abstract}
Spiramycin macrolide antibiotic (SPM) can be photocatalytically degraded on $\mathrm{TiO}_{2}$ (anatase variety). The experiments are done in a batch reactor and the effect of some key parameters is investigated under low energy of artificial UV light. The reaction rate is affected by varying $\mathrm{TiO}_{2} \mathrm{dose}, \mathrm{pH}$ and $\mathrm{SPM}$ concentration. Under optimized conditions, a photodegradation efficiency of $98 \%$ is achieved and the SPM photodegradation follows pseudo-first order kinetics. The LangmuirHinshelwood $(\mathrm{L}-\mathrm{H})$ model is successfully used to fit the experimental data, indicating the dependence of the reaction rate on the chemical reaction step. The $\mathrm{L}-\mathrm{H}$ model led to the determination of both reaction kinetic and adsorption/desorption equilibrium constants. In order to give an overall estimate of the by-products, chemical oxygen demand, total organic carbon, and calculated average oxidation state monitor the photodegradation process.
\end{abstract}

Keywords: spiramycin, photocatalysis, $\mathrm{TiO}_{2}$, Langmuir-Hinshelwood model, kinetic.

Over the last years, many pharmaceutical substances have been detected in the aquatic environment such as analgesics, anti-inflammatory, antibiotics, antiepileptic, beta-blockers, blood lipid regulators, contrast media and cytostatic drugs [1-7]. Their presence and accumulation in natural waters are considered as an emerging pollution problem, leading to the disruption of the ecosystem and increased malfunction in the reproduction of aquatic species [1, 2]. Some authors have reported the difficulty ofremoving pharmaceutical substances, which is often incomplete. For instance, 60-90\% 
removal of pharmaceutical products was reported for the sewage treatment plants [3]. As a result, pharmaceuticals can be found in effluents of sewage treatment plants and in rivers at concentrations as high as milligrams per liter [6].

Among the detected pharmaceutical pollutants, antibiotics and anti-inflammatory drugs are the most frequently encountered in the aquatic medium [7]. The antibiotics attracted special attention because of their increasing consumption by humans and excessive use in food production, thus transforming soil and waters into sources of antibiotic-resistant bacteria. Therefore, these substances cause damages to micro-flora and fauna. Their accumulation in the food chain can accelerate the development of resistant microorganisms like pathogens [8]. Accumulation of antibiotics also provokes arthropathy, nephropathy, genotoxicity and endocrine disruption, damages to the central nervous system, spermatogenesis, mutagenic effects, and light sensitivity [9].

According to recent studies, the spiramycin (SPM) is one of the most abundant macrolide antibiotics detected in wastewaters [5, 7]. Its concentration in the effluent of Sewage Treatment Plants (STP) was detected to values up to $0.6 \mathrm{ng} / \mathrm{L}$. Only about $25 \%$ of spiramycin could be removed with UV light treatment in the same STP. SPM (also called rovamycin) is an effective antibiotic against gram-positive aerobic pathogens, $N$. gonorrhoeae, and staphylococci. It is generally prescribed in the treatment of different types of infections (in both human and veterinary medicine) as toxoplasmosis, to prevent the transmission of toxoplasmosis to the unborn child; and protozoan infections like amoebiasis, balantidiasis, malaria and cryptosporidiosis [10]. SPM is a macrolide antibiotic isolated from Streptomyces ambofaciens and is a natural mixture of SPM I (over 85\%) together with 3-acetyl (SPM II; max. 5\%) and 3-propanoyl esters (SPM III; max. 10\%) (Table 1). The percentage of each SPM in the mixture varies from one manufacturer to another.

Recently, some technological alternatives allowing the removal of antibiotics werereported. They involve reverse osmosis, adsorption on activated carbons, or advanced oxidation technologies, such as Fenton reaction, ozonation, and peroxidation combined with UV light as well asphotocatalysis [11-18]. The latter proved to be effective in the transformation, deactivation and minimization of persistent compounds in water [19]. Several studies have been conducted on the photocatalytic degradation of pharmaceuticals [19-21]. Among the photocatalysts, $\mathrm{TiO}_{2}$ received a special attention due to its chemical stability over the entire $\mathrm{pH}$ range, superior performance, non-toxicity and low cost [22]. The photocatalytic mechanisms were extensively discussed in the literature with $\mathrm{TiO}_{2}$ as the main material used as a catalyst $[23,24]$.

In the present work, SPM was chosen as a target compound and its photocatalytic degradation on $\mathrm{TiO}_{2}$ suspension was a primer goal of the investigation. The reaction parameters, like catalyst dose, 
initial SPM concentration and $\mathrm{pH}$ were optimized to advance monitoring and understanding of the photodegradation. The reaction kinetic was studied and the applicability of the first order kinetic model discussed. The agreement of the experimental results with the $\mathrm{L}-\mathrm{H}$ kinetic model was examined. Furthermore, measurements of chemical oxygen demand (COD), total organic carbon (TOC), and calculated average oxidation state (AOS) were conducted. The goal is to improve the mineralization process and to have an insight into the by-product formation.

\section{MATERIALS AND METHOD}

\section{Chemicals and reagents}

Macrolide antibiotic spiramycin (purity of 98\%), used in this study, was kindly offered by "Sanofi-Aventis Company for Pharmaceutical Industry" (Algeria). The photocatalyst was PC500 Titania $\left(\mathrm{TiO}_{2}\right)$, supplied by "Millennium Inorganic Chemicals". It has a crystallite form, the purity of anatase is $99 \%$, mean crystallite size is $5-10 \mathrm{~nm}$ and a specific area is $320 \mathrm{~m}^{2} / \mathrm{g} . \mathrm{KH}_{2} \mathrm{PO}_{4}, \mathrm{~K}_{2} \mathrm{HPO}_{4}$, $\mathrm{KOH}$ and $\mathrm{HCl}$ used for the preparation of buffer solutions were of reagent grade and supplied from "Biochem, Chemopharma". The point of zero charge (PZC) of $\mathrm{TiO}_{2}$ was measured with a digital pH meter (Schott 825) in an aqueous suspension at equilibrium $\mathrm{pH}$. All solutions were prepared from distilled water (resistivity of $2 \mathrm{M} \Omega \mathrm{cm}$ ).

\section{Experimental procedure and analytical methods}

The photocatalytic experiments were carried out using a batch photoreactor. It consists of a cylindrical borosilicate glass reactor vessel with an effective volume of $0.6 \mathrm{~L}$ and a cooling water jacket which maintains the reaction temperature at $(20 \pm 2)^{\circ} \mathrm{C}$. The UV light source (Philips PL-S $9 \mathrm{~W} / 10 / 4 \mathrm{P}$ mercury vapor lamp) emits radiation in the range $\left(350-400 \mathrm{~nm}, \lambda_{\max }=365 \mathrm{~nm}\right)$; it is placed in a Pyrex tube and positioned axially in the center. For all tests, the incident light intensity was maintained at a value of $45 \mathrm{~W} / \mathrm{m}^{2}$ and measured by a radiometer (VLX-3W, "Vilbert Lourmat", France). The solution was magnetically stirred before and during irradiation to ensure a homogeneous mixing of the powdered catalyst.

The solutions were prepared by dissolving SPM in water without $\mathrm{pH}$ adjustment. Only in experiments dealing with the effect of $\mathrm{pH}$ on the antibiotic degradation initial $\mathrm{pH}$ was adjusted with buffer solutions and measured with WTW inoLab Level 1 electrode. Afterwards, $\mathrm{TiO}_{2}$ powder was added to the solution and the resulting suspension was stirred again for $30 \mathrm{~min}$ in the darkness to 
ensure that the adsorption equilibrium was reached. Then, the light was turned on and the irradiation was conducted for $300 \mathrm{~min}$.

The aliquots were sampled over the illumination time and filtered through $0.45 \mu \mathrm{m}$ PTFE Millipore syringe filter for the analysis. The SPM concentration was monitored by ultra-high performance liquid chromatography (UHPLC) at $\lambda_{\max }(=232 \mathrm{~nm})$ equipped with a photodiode-array detector (Acquity Hclass: "Waters"). The injection volume and flow rate were respectively $10 \mu \mathrm{L}$ and $0.4 \mathrm{~mL} / \mathrm{min}$. Chromatographic separation was performed with a BEH C18 reversed phase column (100 $\mathrm{mm} \times 2.1 \mathrm{~mm}$ i.d. $\times 1.7 \mu \mathrm{m})$ at $30^{\circ} \mathrm{C}$. The mobile phase was $0.1 \%$ aqueous solution of formic acid in acetonitrile ACN/ultra-pure water $(20: 80, v / v)$. TOC analysis was carried out with a Shimadzu Analytical 1010 instrument. COD was determined with a commercial reagents kit $(\mathrm{HACH})$ in a Fisherbrand Thermoreactor ECO8 and a spectrophotometer according to a previously calibrated graph.

\section{RESULTS AND DISCUSSION}

In the absence of $\mathrm{TiO}_{2}$, the concentration of SPM shows no significant variation, indicating that spiramycin cannot be degraded by photolysis. Hence, any change in the SPM concentration can be attributed to the photocatalytic process. The pseudo-first-order kinetic model is usually used to fit all data sets (catalyst concentration, initial pH solution and initial SPM concentration $\left(\mathrm{C}_{0}, \mathrm{mg} / \mathrm{L}\right)$ ). The L$\mathrm{H}$ model, generally used to investigate the mechanism of heterogeneous photocatalytic reactions, can be simplified to describe the apparent first-order reaction for diluted solutions $(<<1 \mathrm{mmol})$ [24]:

$$
\ln \left(\frac{C_{0}}{C}\right)=k_{\mathrm{ap}} . t
$$

The apparent reaction rate constant $k_{\mathrm{ap}}\left(\mathrm{min}^{-1}\right)$ is given by the slope of the graph of $\ln \left(C_{0} / C\right)$ vs time $t$ (min).

\section{Effect of catalyst dose}

$\mathrm{TiO}_{2}$ dose is considered as an important parameter in slurry photocatalytic processes. The determination of the optimal catalyst dose depends on the nature of the organic pollutant, as well as the photoreactor's geometry [25]. The effect of $\mathrm{TiO}_{2}$ dose is studied over the range $(0-1.2 \mathrm{~g} / \mathrm{L})$ with $\mathrm{C}_{0}=$ $20 \mathrm{mg} / \mathrm{L}$ and natural $\mathrm{pH}(6.5 \pm 0.2)$. 
The variation of the degradation rate with the catalyst dose is illustrated in Fig.1. At low doses, $\mathrm{TiO}_{2}$ absorbs an insignificant number of photons and most of them pass through the solution resulting in a low activity. The rate constant increases with increasing the $\mathrm{TiO}_{2}$ dose to reach an optimum of $0.0262 \mathrm{~min}^{-1}$ for a dose of $1 \mathrm{~g} / \mathrm{L}$. Accordingly, the larger amounts of the catalyst favor the degradation efficiency. The same trend was earlier reported [26, 27] with similar values of the reaction rate constants found by other researchers for photocatalytic degradation of antibiotics [22]. This effect is due to the increase in the number of active sites leading to an enhanced formation of free radicals $\mathrm{O}_{2}{ }^{\circ}$ and/or $\mathrm{OH}$. At high doses, the opacity and aggregation of catalyst particles led to a deviation from linearity. Further increase in the catalyst dose $(>1 \mathrm{~g} / \mathrm{L})$ does not improve the SPM degradation. This result can be explained by the fact that high catalyst doses favor the scattering effect and hence decrease the light penetration, which in turn reduces the photodegradation efficiency. The shadowing effect also accounts for the decreased activity. According to previous works [26, 28], the reaction order is deduced from the equation:

$$
\ln k_{\mathrm{ap}}=\ln k_{1}+n \ln \left[\mathrm{TiO}_{2}\right]
$$

The semi-log plot of the rate constant against the catalyst dose results in a straight line with a slope of 0.39 (equal to the reaction order) and an intercept of -3.68 (Fig. 1). Thus, the initial degradation rate of SPM can be expressed by the relation:

$k_{\mathrm{ap}} \approx 2.53 \times 10^{-2}\left[\mathrm{TiO}_{2}\right]^{0.39}$.

Similar results have been reported by Galindo et al. [28] for the photodegradation of dyes with a reaction order less than 1. A suggestion was made that the presence of the catalyst in increased amounts leads to a larger fraction of absorbed incident photons. The number of adsorbed substrate molecules increases as well, due to increasing number of the catalyst particles. However, the empirical relation (Eq.3) can only be applied to low $\mathrm{TiO}_{2}$ doses. To be sure that the results obtained on examining the role of other operating parameters in the reaction patterns and the kinetic features are reproducible, the optimal catalyst dose was taken equal to $1 \mathrm{~g} / \mathrm{L}$.

\section{Influence of $\mathrm{pH}$}

Another important parameter in photocatalysis is $\mathrm{pH}$, which influences the surface charge of $\mathrm{TiO}_{2}$ and therefore adsorption of the pollutant. The experiments were performed over the $\mathrm{pH}$ range 
2.85-9.92. A maximum SPM removal (97\%) after irradiation time of $300 \mathrm{~min}$ was obtained at $\mathrm{pH}$ values of 6.09 (natural solution) and 8 .

Generally, the degradation rate varies with the initial $\mathrm{pH}$, due to the surface properties of the catalyst. Since $\mathrm{TiO}_{2}$ is amphoteric and its $\mathrm{PZC}$ changes in the $\mathrm{pH}$ range 4.5-7.0 as reported by many authors [23, 29], the ionic nature of the pollutant is also altered [30]. Figure 2 shows that the $\mathrm{pH}$ strongly affects the SPM degradation, and the decay is much faster in a weak basic solution (pH 8) than in acidic and neutral media. In fact, the rate constant $k_{\text {ap }}$ declines slightly under acidic conditions ( $\mathrm{pH}$ range 2.85-4.12), then remains nearly constant up to $\mathrm{pH} \sim 6$ and increases to peak at $\mathrm{pH} 8$, above which it decreases drastically. The reaction with water $\left(\mathrm{H}_{2} \mathrm{O}+2 \mathrm{e}^{-} \rightarrow \mathrm{H}_{2}+2 \mathrm{OH}^{-}\right)$also accounts for the reduction in the activity. Therefore an optimal $\mathrm{pH} \sim 8$ is needed to enhance the SPM photodegradation.

The effect of $\mathrm{pH}$ on the photodegradation may be explained by the surface charge of $\mathrm{TiO}_{2}$ and its relation with dissociation of SPM in acid solutions. The ionization state of $\mathrm{TiO}_{2}$ surface can be protonated and deprotonated respectively in acidic and alkaline solutions, according to the following equations [24]:

$$
\begin{aligned}
& \mathrm{TiOH}+\mathrm{H}^{+}=\mathrm{TiOH}_{2}^{+}, \\
& \mathrm{TiOH}+\mathrm{OH}^{-}=\mathrm{TiO}^{-}+\mathrm{H}_{2} \mathrm{O} .
\end{aligned}
$$

SPM is a weak acid with $\mathrm{p} K_{\mathrm{a}}$ of 8 and the amino and hydroxyl groups of the molecule can be protonated and deprotonated respectively, depending on the $\mathrm{pH}$. A value of the $\mathrm{PZC}$ was found to be 6.2 for $\mathrm{TiO}_{2}$; over the $\mathrm{pH}$ range between 6.2 and 8 the catalyst surface is negatively charged and the amino groups are protonated. Correspondingly, the electrostatic attraction of $\mathrm{TiO}_{2}$ with the ionized form increases the amount of SPM adsorbed on $\mathrm{TiO}_{2}$ particles and therefore promotes the photocatalytic reaction. Besides, at higher $\mathrm{pH}(>8)$, the slight decrease in the degradation rate could be attributed to the electrostatic repulsion between negatively charged ionized molecules formed by deprotonation and negatively charged $\mathrm{TiO}_{2}$ surface. Finally, at high values of $\mathrm{pH}$, the $\mathrm{OH}$ radicals may be scavenged [31] and do not have the opportunity to react with pollutant molecules. Similar results were reported by other authors [11, 26, 32, 33].

On the other hand, the fast reaction rate observed at extreme acidic conditions can be attributed to the variation of the effective diameter of the catalyst nanoparticles. As reported recently by Chen and Chu [11], small crystallites size offer larger surface area at low $\mathrm{pH}$ with a better contact, thus providing more opportunity for the radicals to react with SPM molecules under UV light. It can be thus inferred that the use of alkaline conditions is an appropriate option to obtain a high efficiency for SPM 
photodegradation. However, considering the chemical cost and the experimental practice, natural $\mathrm{pH}$ condition is chosen for further work.

\section{Effect of initial SPM concentration}

In real effluents, the antibiotics can be encountered in concentrations as high as milligrams per liter. It is therefore of interest to study the effect of the initial concentration of SPM on the photodegradation. The kinetic of SPM degradation over the $C_{0}$ range of $5-80 \mathrm{mg} / \mathrm{L}$ is investigated at constant $\mathrm{TiO}_{2}$ dose $(1 \mathrm{~g} / \mathrm{L})$ and natural $\mathrm{pH}(6.68 \pm 0.20)$. It is observed that the time required for the maximum degradation depends on $C_{0}$. For the concentrations used in the experiments and at irradiation time of 300 min the extent of the SPM removal is between 66 and 98\%. As expected, a maximum degradation is observed at low concentrations $(5-40 \mathrm{mg} / \mathrm{L})$ and the reaction rate constant varies with

Fig. $3 C_{0}$ (Fig. 3), indicating that the first order kinetics cannot be applied in our case. This result can be explained by adsorption/desorption competition between the SPM molecules and the degradation of intermediate products, which may be predominant at high concentrations. In addition, the amounts of available reactive species formed on the catalyst surface can be insufficient when the concentration of antibiotic is fairly high. Consequently, the degradation of SPM decreases with increasing $C_{0}$ and the L$\mathrm{H}$ model is suitable to describe such phenomenon. This model is commonly used to rationalize the mechanisms of reactions occurring on solid surfaces [34]. A three-step reaction mechanism including adsorption, chemical reaction and desorption is the kinetic model that is most frequently applied in the heterogeneous photocatalysis. The model assumes the chemical reaction as the rate determining step. According to the $\mathrm{L}-\mathrm{H}$ model, the initial degradation rate can be expressed as:

$$
r_{0}=-\frac{d C_{0}}{d t}=\frac{K_{\mathrm{L}} k_{\mathrm{L}-\mathrm{H}} C_{0}}{1+K_{\mathrm{L}} C_{0}} \text {, }
$$

where $k_{\mathrm{L}-\mathrm{H}}$ is the apparent $\mathrm{L}-\mathrm{H}$ rate $\left(\mathrm{mg}^{-1} \mathrm{~L} \min \right)$ and $K_{\mathrm{L}}$ the adsorption/desorption equilibrium constant $(\mathrm{L} / \mathrm{mg})$. The linearization form of $\mathrm{L}-\mathrm{H}$ model leads to:

$$
\frac{1}{r_{0}}=\frac{1}{k_{\mathrm{L}-\mathrm{H}} K_{\mathrm{L}}} \cdot \frac{1}{C_{0}}+\frac{1}{k_{\mathrm{L}-\mathrm{H}}}
$$


The constants $k_{\mathrm{L}-\mathrm{H}}\left(0.7561 \mathrm{mg} \mathrm{L}^{-1} \mathrm{~min}^{-1}\right)$ and $K_{\mathrm{L}}(0.04 \mathrm{~L} / \mathrm{mg})$, determined by linear regression of the Fig. 4 plot $1 / r_{0}$ vs $1 / C_{0}$ (Fig. 4), are of the same order of magnitude than those reported in literature for the photodegradation of antibiotics $[22,27,35,36]$. These results confirm that the $\mathrm{L}-\mathrm{H}$ model is suitable to describe the kinetic of SPM degradation under the investigated conditions.

\section{SPM mineralization over different initial concentrations}

It can be postulated that the SPM degradation in the presence of illuminated $\mathrm{TiO}_{2}$ proceeds in several steps, leading to the formation of by-products, which can be more toxic than SPM itself. COD and TOC are of great help to provide an overall estimation of the photocatalytic performance of SPM degradation. These characteristics are used to evaluate the total concentration of organic compounds remaining in the solution after 300 min of irradiation. The plots describing the COD values as a that the SPM oxidation is fast at low concentrations $\left(C_{0}=10 \mathrm{mg} / \mathrm{L}\right)$, generating after large periods of irradiation, stable intermediates. The values of COD abatements recorded after 2 and $5 \mathrm{~h}$ of irradiation are given in Table 2.

To estimate the degree of mineralization, we also determined TOC. The variation of the

Fig. 6 normalized TOC values vs irradiation time is shown in Fig. 6 for different SPM concentrations $C_{0}$. It can be seen that the irradiation for $5 \mathrm{~h}$ is required to reach the degree of mineralization of $50 \%$ for the solution with initial concentrations of $C_{0}$ of 10 and $20 \mathrm{mg} / \mathrm{L}$ and only $20 \%$ mineralization can be reached for solutions with $C_{0}$ equal to 40 and $80 \mathrm{mg} / \mathrm{L}$ (Table 2). After irradiation for $5 \mathrm{~h}$ a maximum abatement of the antibiotic can be observed. It is noted that even after complete degradation of SPM, for an irradiation time of $300 \mathrm{~min}$, TOC values remain high, suggesting the presence of organic intermediates generated during the photocatalysis. Such intermediates are not identified; their nature is broadly monitored by the changes of AOS. AOS is calculated according to the following equation:

$$
\mathrm{AOS}=\frac{4(\mathrm{TOC}-\mathrm{COD})}{\mathrm{TOC}}
$$

where TOC and COD are expressed in $\mathrm{mg} / \mathrm{L}$ of $\mathrm{C}$ and $\mathrm{O}_{2}$, respectively [37]. Some authors reported that the maximal AOS value $(+4)$ corresponds to carbon atoms in the highest state of oxidation $\left(\mathrm{CO}_{2}\right)$ while the lowest value (-4) represents carbon atoms in the most reduced state $\left(\mathrm{CH}_{4}\right)$ [38]. According to the same authors, the different values of AOS can be assigned to benzene $(-1)$, oxalic acid $(+3)$, formaldehyde and acetic acid (0), and formic acid (+2). An example for AOS profileobtainedfor long- 
lived SPM intermediates is represented in Fig. 7. AOS increases from initial value $(\sim-4)$ to about $(+2)$ after $120 \mathrm{~min}$ of irradiation, when the antibiotic is almost completely eliminated. As previously stated, these AOS values correspond to low carboxylic acids, which are known as recusant for the mineralization. These results are in agreement with the low mineralization abatements observed even after long irradiation times. The knowledge of intermediates requires an analysis by combined UHPLC/GCMS. The study is currently under way and will be reported in a future paper.

\section{CONCLUSIONS}

The present study showed that a maximum abatement of SPM by heterogeneous photocatalysis is reached under optimum conditions, i.e., low UV power, small SPM concentrations, natural $\mathrm{pH}$ and catalyst dose of $1 \mathrm{~g} / \mathrm{L}$. The use of low energy consumption UV light source can lead to an improved efficiency of the SPM oxidation. The reaction rate follows pseudo-first order kinetics and the Langmuir-Hinshelwood model was successfully applied regardless of the initial pollutant concentration. The $\mathrm{L}-\mathrm{H}$ constants are of the same order of magnitude as those reported in literature. The chemical reaction is considered to be the limited step. The parameters COD, TOC and AOS gave an overview of SPM mineralization and therefore abroad idea of the formed by-products. The study is continuing for the determination of by-products through chromatography and mass spectrometry. These issues are considered in ongoing work.

\section{ACKNOWLEDGEMENTS}

The authors wish to express their appreciation to M. Lyes Chabane Chaouch, teacher of English at ALC Algiers, for proof reading and editing the present manuscript and Dr. Maamar Fedailine for his assistance.

\section{REFERENCES}

[1]Gracia-Lor, E., Sancho, J.V., Serrano, R., Hernandez, F., Chemosphere, 2012, Vol. 87, p. 453. [2]Heberer, T., Toxicol.Lett., 2002, Vol. 131, p. 5.

[3]Hirsch, R., Ternes, T., Haberer, K., Kratz, K.L., 1999, Sci.Total.Environ., Vol. 225, p. 109. 
[4] Ullah, Z., Khan, H., Waseem, A., Mahmood, Q., Farooq, U., J. Water Chem. Tech., 2013, Vol. 35, p. 170.

[5]Michael, I., Rizzo, L., McArdell, C.S., Manaia, C.M., Merlin, C., Schwartz, T. Dagot, C., FattaKassinos,D., Water. Res., 2013, Vol. 47, p. 957.

[6]Ternes, T.A., Water Res., 1998, Vol. 32, p. 3245.

[7]Zuccato, E., Castiglioni, S., Bagnati, R., Melis, M., Fanelli, R., J. Hazard. Mater., 2010,Vol. 179, p. 1042.

[8]Halling-Sørensen, B., Nors Nielsen, S., Lanzky, P.F., Ingerslev, F. Holten Lützhøft,H.C., Jørgensen,S.E., Chemosphere, 1998, Vol. 36, p. 357.

[9]Kümmerer, K., Al-Ahmad, A.,Mersch-Sundermann, V.,Chemosphere, 2000, Vol.40, p. 701.

[10]Civitareale, C., Fiori, M., Ballerini, A., Brambilla, G., J. Pharm. Biomed. Anal., 2004, Vol. 36, p. 317.

[11]Chen,M. andChu, W., J. Hazard. Mater., 2012, Vol. 183, p. 219.

[12]Elmolla,E.S. and Chaudhuri, M., J. Hazard. Mater., 2009, Vol. 172, p. 1476.

[13]Kim, K.S., Yang, C.S., Mok, Y.S., Chem. Eng. J., 2013,Vol. 219, p. 19.

[14] Kochkodan, V. M., Rolya, E. A., Goncharuk, V. V., J. Water Chem. Tech., 2009, Vol. 31, p. 227.

[15]Nasuhoglu, D., Rodayan, A., Berk, D., Yargeau, V., Chem. Eng. J., 2012,Vol. 189, p. 41.

[16]Putra, E.K., Pranowo, R., Sunarso, J., Indraswati, N., Ismadji, S.,Water Res., 2009, Vol. 43, p. 2419.

[17] Darwich, C., Elkhatib, M., Steinhauser, G., Delalu, H., Kinet. Catal., 2009, Vol. 50, p. 103.

[18] Moghaddam, S. K., Rasoulifard, M., Vahedpour, M., Eskandarian, M., Korean J. Chem. Eng., 2014. Vol. 31, p. 1577.

[19] Doll,T.E. and Frimmel, F.H., Catal. Today, 2005, Vol.101, p. 195.

[20] Vorontsov, A. V., Kozlov, D. V., Smirniotis, P. G., Parmon, V. N., Kinet. Catal., 2005, Vol. 46, p. 189.

[21] Pronin, I. A., Kaneva, N. V., Bozhinova, A. S., Averin, I. A., Papazova, K. I., Dimitrov, D. T., Moshnikov, V. A., Kinet. Catal., 2014, Vol. 55, p. 167.

[22]Yang, H., Li, G., An, T., Gao, Y., Fu, J., Catal. Today, 2010, Vol. 153, p. 200.

[23]Chong, M.N., Jin, B., Chow, C.W.K., Saint, C., Water Res., 2010, Vol. 44, p. 2997.

[24]Gaya, U.I., Abdullah, A.H.,J. Photochem.Photobiol. C: Photochem. Rev., 2008, Vol. 9, p. 1.

[25]Parra, S., Olivero, J., Pulgarin, C.,App. Catal. B: Environment,2002, Vol. 36, p. 75.

[26]Gad-Allah, T.A., Ali, M.E., Badawy, M.I., J. Hazard. Mater., 2011,Vol. 186, p. 751.

[27]Kaniou, S., Pitarakis, K., Barlagianni, I., Poulios, I.,Chemosphere, 2005, Vol. 60, p. 372. 
[28]Galindo, C., Jacques, P., Kalt, A., Chemosphere, 2001,Vol. 45, p. 997.

[29]Malato, S., Fernández-Ibáñez, P., Maldonado, M.I., Blanco, J., Gernjak, W., Catal.Today, 2009, Vol. 147, p. 1.

[30]Abellán, M., Bayarri, B., Giménez, J., Costa, J.,App. Catal. B: Environment,2007, Vol. 74, p. 233.

[31]Sakkas, V., Calza, P., Medan, C., Villioti, A.E., Baiocchi, C., Pelizzetti, E., Albanis, T., App. Catal. B: Environment, 2007, Vol.77, p. 135.

[32]Chu, W., Choy, W., So, T., J. Hazard. Mater., 2007, Vol. 141, p. 86.

[33]Haque,M. and Muneer, M., J. Hazard. Mater., 2007, Vol.145, p. 51.

[34]Kumar, K.V., Porkodi, K., Rocha, F., Catal. Commun., 2008, Vol. 9, p. 82.

[35]Chatzitakis, A., Berberidou, C., Paspaltsis, I., Kyriakou, G., Sklaviadis, T., Poulios, I., Water Res., 2008, Vol.42, p. 386.

[36]Dimitrakopoulou, D., Rethemiotaki, I., Frontistis, Z., Xekoukoulotakis, N.P., Venieri, D., Mantzavinos, D.,J. Environ.Manage., 2012, Vol.98, p. 168.

[37]Reyes, C., Fernández, J., Freer, J., Mondaca, M.A., Zaror, C., Malato, S., Mansilla, H.D., J. Photochem. Photobiol. A: Chemistry, 2006, Vol.184, p. 141.

[38] Palominos, R., Mora, A., Mondaca, M.A., Pérez-Moya, M., Mansilla, H.D., J. Hazard. Mater., 2008, Vol. 158, p. 460.

TABLES

Table 1. Properties of spiramycin

\begin{tabular}{|l|c|}
\hline Name & Spiramycin \\
\hline
\end{tabular}




\begin{tabular}{|l|ccc|}
\hline Structure & \multicolumn{3}{|c|}{} \\
\hline$\lambda_{\text {max }}, \mathrm{nm}$ & $\mathrm{CO}-\mathrm{CH}_{3}$ & $\mathrm{CO}_{-} \mathrm{CH}_{2}-\mathrm{CH}_{3}$ \\
\hline Radical & $\mathrm{H}$ & $\mathrm{CH}_{45} \mathrm{H}_{76} \mathrm{~N}_{2} \mathrm{O}_{15}$ & $\mathrm{C}_{46} \mathrm{H}_{78} \mathrm{~N}_{2} \mathrm{O}_{15}$ \\
\hline Molecular formula & $\mathrm{C}_{43} \mathrm{H}_{74} \mathrm{~N}_{2} \mathrm{O}_{14}$ & 899.1 \\
\hline Molecular weight, $\mathrm{g} / \mathrm{mol}$ & 843.1 & 885.1 & 899.1 \\
\hline
\end{tabular}

Table 2. COD and TOC abatement after irradiation for different initial SPM concentrations over illumination times

\begin{tabular}{|c|c|c|c|c|}
\hline \multirow{2}{*}{$C_{0}$} & \multicolumn{4}{|c|}{ Values of abatement, } \\
\cline { 2 - 5 } & \multicolumn{3}{|c|}{ COD } & \multicolumn{2}{c|}{ TOC } \\
\cline { 2 - 5 } $\mathrm{mg} / \mathrm{L}$ & $120 \mathrm{~min}$ & $300 \mathrm{~min}$ & $150 \mathrm{~min}$ & $300 \mathrm{~min}$ \\
\hline 10 & 87.0 & 100 & 30.0 & 54.4 \\
20 & 43.9 & 67.7 & 17.8 & 40.3 \\
40 & 33.0 & 71.7 & 8.15 & 25.5 \\
80 & 7.5 & 15.5 & 9.0 & 16.2 \\
\hline
\end{tabular}




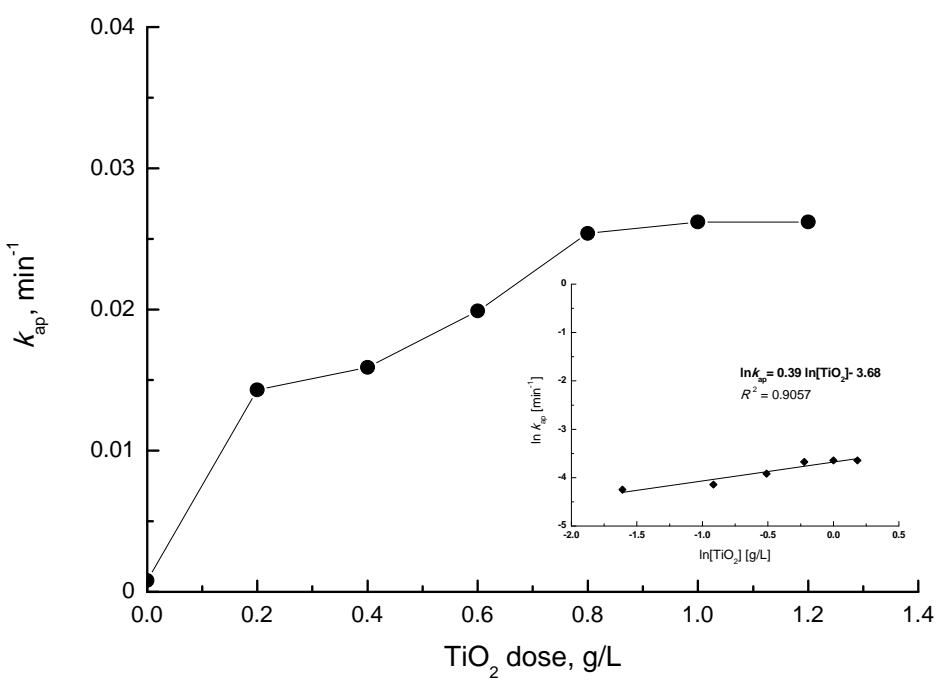

Fig. 1. Effect of the catalyst dose on the reaction rate constant for spiramycin degradation. $C_{0}=20 \mathrm{mg} / \mathrm{L}$, initial pH 6.5. 


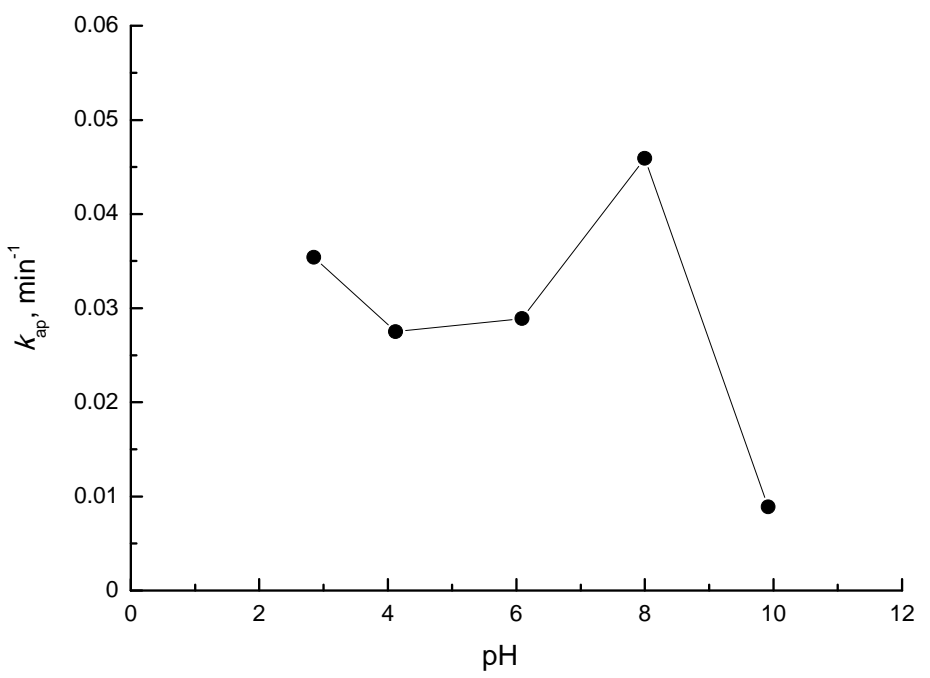

Fig. 2. Effect of the initial $\mathrm{pH}$ on the reaction rate constant for spiramycin degradation. $C_{0}=20 \mathrm{mg} / \mathrm{L}$, $\left[\mathrm{TiO}_{2}\right]=1 \mathrm{~g} / \mathrm{L}$. 


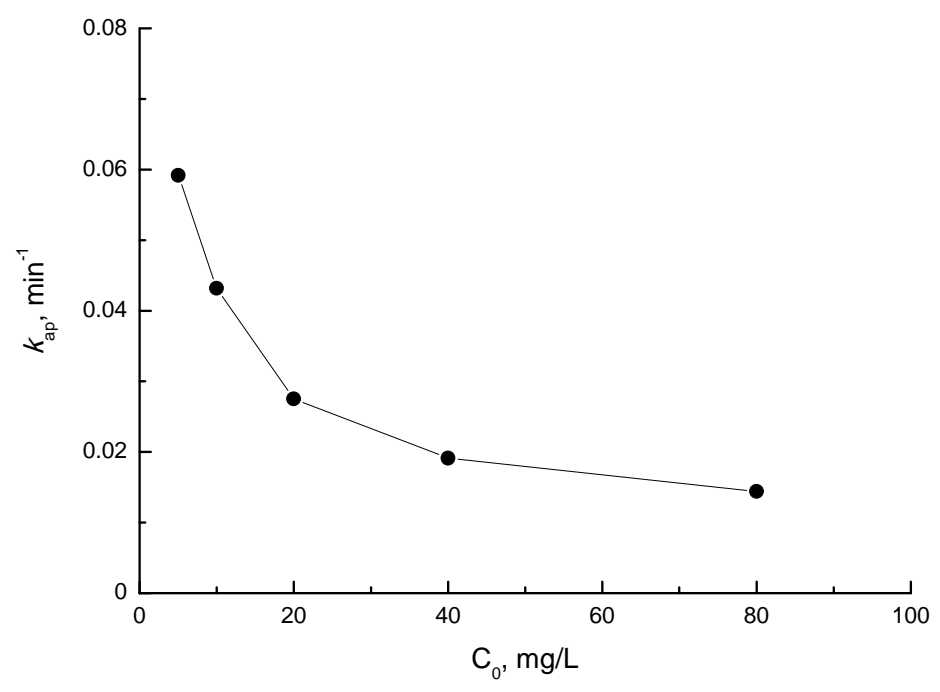

Fig. 3. The reaction rate constant for spiramycin degradation as a function of the initial concentration of spiramycin. $\left[\mathrm{TiO}_{2}\right]=1 \mathrm{~g} / \mathrm{L}$, initial $\mathrm{pH} 6.68$. 


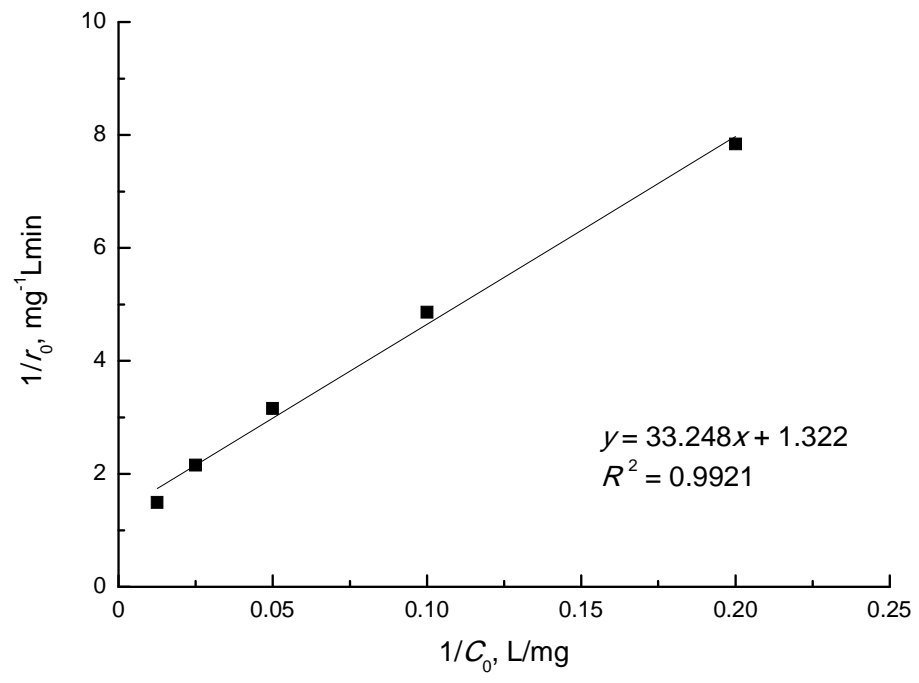

Fig. 4. Langmuir-Hinshelwood model application for spiramycin degradation process. 


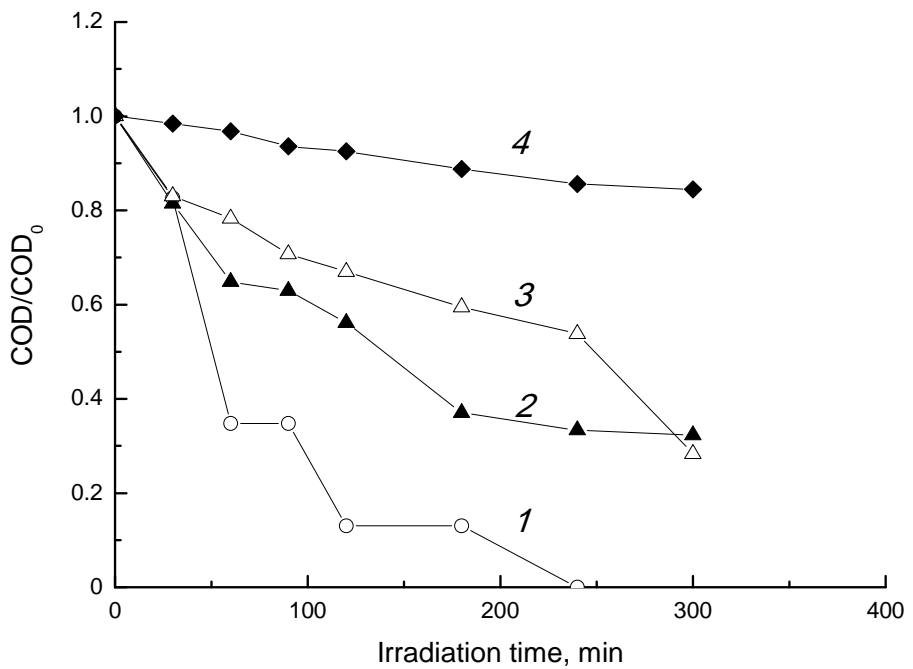

Fig. 5. Normalized COD concentrations as a function of the irradiation time for different initial concentrations of spiramycin $C_{0}, \mathrm{mg} / \mathrm{L}: 1-10,2-20,3-40,4-80$. 


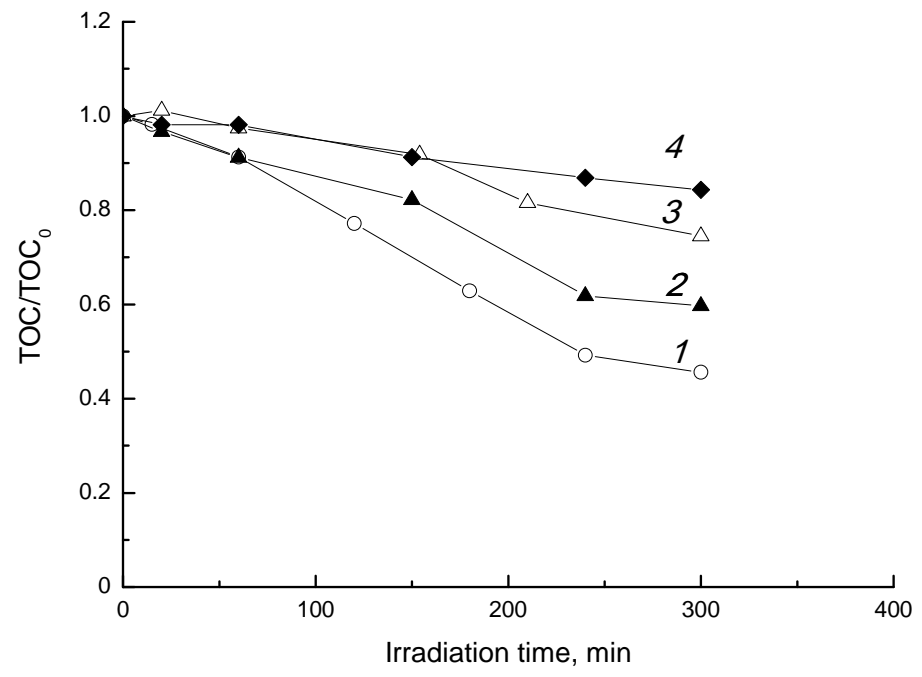

Fig. 6. Normalized TOC concentrations as a function of the irradiation time for different initial concentrations of spiramycin $C_{0}, \mathrm{mg} / \mathrm{L}: 1-10,2-20,3-40,4-80$. 


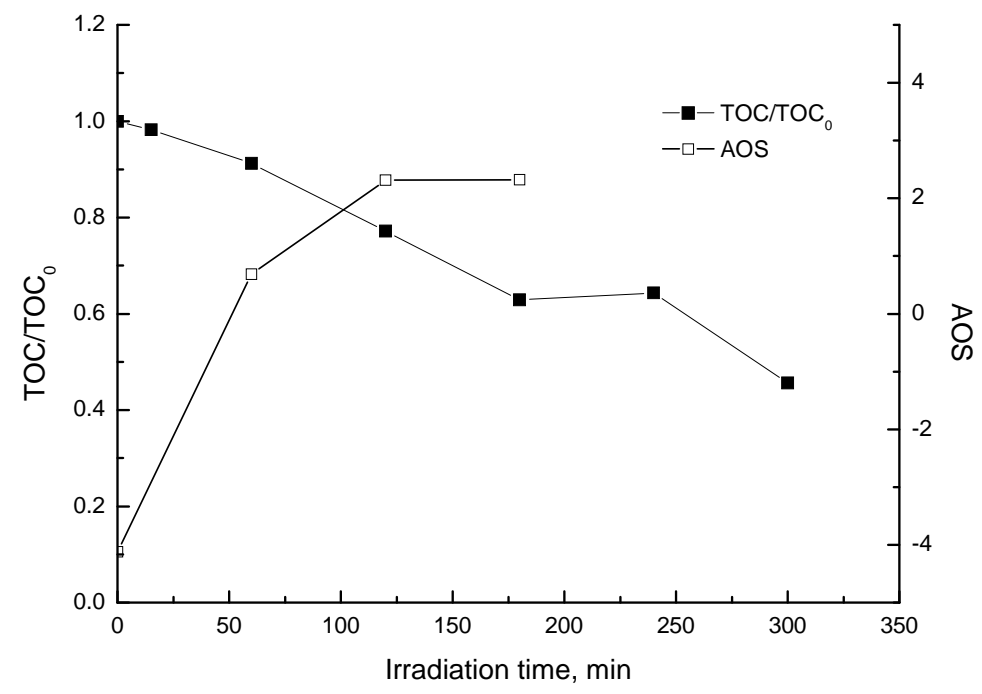

Fig. 7. AOS and reduced TOC evolution over irradiation time for initial spiramycin concentration $C_{0}=$ $10 \mathrm{mg} / \mathrm{L}$. 